\title{
Molecular detection of Rickettsia spp. in ticks collected from dogs from the Department of Piura, Peru
}

\section{Deteç̧ão molecular de Rickettsia spp. em carrapatos coletados de cães provenientes do Departamento de Piura-Peru}

\author{
Luis Fernando Cerro Temoche ${ }^{1 *}$; Eloy da Silva Seabra Junior ${ }^{2}$; \\ Matheus Dias Cordeiro' ${ }^{3}$; Adivaldo Henrique da Fonseca ${ }^{4}$; \\ Nathalie Costa da Cunha ${ }^{5}$ : Nadia Regina Pereira Almosny ${ }^{5}$
}

\begin{abstract}
The aim of this study was to determine the frequency of ticks positive for genus Rickettsia bacteria among ticks collected from domestic dogs in the Department of Piura, Peru, using polymerase chain reaction (PCR) analysis. Ticks were collected from dogs in urban areas of the metropolitan region of Piura, Peru. Only three species of ticks were identified; 977 Rhipicephalus sanguineus (180 nymphs, 417 females, and 380 males), Six Amblyomma triste females, and one Amblyomma tigrinum male. After classifying the specimens morphologically by stage, species, and sex, their total DNA was tested by PCR using primers that amplify fragments of the gltA, отрA, отрB, and htrA genes. The resulting positive sample was sequenced, compared to the GenBank database, and analyzed phylogenetically. The Rickettsia spp. infection rate in the tick pools was $0.2 \%(1 / 484)$; the positive specimen was an $R$. sanguineus tick. GenBank analysis of the positive sequence revealed $100 \%$ identify with Rickettsia felis; however, no products of the $h t r A$, ompA and $о т р B$ genes were amplified from this sample. To the best of our knowledge, this is the first report of $R$. felis in $R$. sanguineus in Peru.
\end{abstract}

Key words: Acari. Ixodidae. Molecular analysis. Rickettsiosis. South America.

\section{Resumo}

O objetivo do presente estudo foi determinar a frequência de carrapatos coletados de caninos domésticos positivos para bactérias do gênero Rickettsia por meio da Reação em cadeia da polimerase (PCR) no Departamento de Piura, Peru. Desta forma, carrapatos foram coletados de caninos de zonas urbanas da região Metropolitana de Piura, Peru. Apenas três espécies de carrapatos foram identificadas, sendo 977 R. sanguineus (180 ninfas, 417 fêmeas e 380 machos), 6 fêmeas da espécie Amblyomma triste e um macho Amblyomma tigrinum. Após classificados morfologicamente por estádio, espécie e sexo, o DNA total dos espécimes foi testado pela PCR utilizando iniciadores que amplificam fragmentos dos genes gltA, ompA, ompB e htrA. A amostra positiva foi sequenciada, comparada com o banco de dados depositados no GenBank e analisada filogeneticamente. Verificou-se, mediante PCR, uma taxa de

\footnotetext{
${ }^{1}$ Discente de Pós-Graduação em Medicina Veterinária, Universidade Federal Fluminense, UFF, Niterói, RJ, Brasil. E-mail: luis_ cerro@hotmail.com

2 Pesquisador, UFF, Niterói, RJ, Brasil. E-mail: eloyseabrajr@gmail.com

3 Pesquisador, Universidade Federal Rural do Rio de Janeiro, UFRRJ, Seropédica, RJ, Brasil. E-mail: mathcordeiro@hotmail.com

4 Prof., UFRRJ, Seropédica, RJ, Brasil. E-mail: adivaldo@ufrrj.br

5 Profas ${ }^{\text {as }}$ UFF, Niterói, RJ, Brasil. E-mail: nathaliecunha@id.uff.br; nadiaalmosny@id.uff.br

* Author for correpondence
} 
infecção de 0,2\% (1/484) "pools" de carrapatos positivos para Rickettsia spp. O espécime positivo foi um carrapato Rhipicephalus sanguineus. A análise no GenBank da sequência positiva apresentou uma similaridade de $100 \%$ com a espécie R. felis. Essa amostra não amplificou produtos para os genes htrA, ompA e ompB. Este é o primeiro relato de R. felis em R. sanguineus no Peru.

Palavras-chave: Acari. Ixodidae. Análise molecular. Rickettsiosis. América do Sul.

Genus Rickettsia bacteria belong to the alpha subdivision of the class Proteobacteria. This genus is subdivided into four groups: 1) the typhus group (TG); 2) the spotted fever group (SFG), containing $>20$ species; 3) the transitional group, represented by species such as $R$. akari, $R$. australis, and $R$. felis; and 4) the basal group (LABRUNA et al., 2011).

The geographic reach of spotted fever (SF) is entirely determined by vector (tick) distribution and activity. In Mexico, Rhipicephalus sanguineus has been implicated as a vector of $R$. rickettsii. This intradomiciliary tick mainly parasitizes domestic dogs, but can also parasitize humans; thus, it could play an important role as a vector in some endemic areas with specific ecological characteristics (EREMEEVA et al., 2011).

A number of studies have reported the presence of several genera of ticks in different regions of Peru, such as Piura; the genera Amblyomma, Dermacentor, Ixodes, and Rhipicephalus have been detected on dogs and other hosts. Furthermore, there is also molecular evidence of the presence of rickettsial agents in ticks in these regions (FORSHEY et al., 2010).

Advances in laboratory techniques for the study of different agents, especially molecular biology methods, have enabled the identification of new species around the world, as well as pathogenic species in both dogs and tick triturates in areas or continents without previous reports (EREMEEVA et al., 2011; FORSHEY et al., 2010).

The clinical importance of these agents, the large population of hemoparasite vectors, and the fact that many of these parasites have zoonotic potential, emphasize the need to characterize the agents present in the northern region of Peru in order to delineate control strategies and diagnostic methods and to further elucidate the epidemiological characteristics of dog infections caused by these agents.

Thus, the aim of this study was to determine the frequency of genus Rickettsia in domestic canine ticks from the metropolitan region of the Piura Province, Department of Piura, Peru, using polymerase chain reaction (PCR) analysis and to examine the frequency of Rickettsia felis in Rhipicephalus sanguineus ticks.

This study was approved by the PRÓ-REITORIA DE PESQUISA E PÓS-GRADUAÇÃO (Office of the Vice-President for Research and Graduate Studies) Animal Research Ethics Committee (CEPA), registration number 759 .

This was a cross-sectional study with convenience sampling. Samples were obtained from dogs in urban areas of the Piura metropolitan region, located in the central zone of the Department of Piura, Peru (Figure 1) at an altitude of 29 meters above sea level, latitude $4^{\circ} 59^{\prime} 24.00^{\prime \prime} \mathrm{S}$, and longitude $80^{\circ} 24^{\prime} 36.00^{\prime \prime} \mathrm{W}$ (Greenwich). The region is characterized by maximum and minimum annual average temperatures of 31.2 and $17.7{ }^{\circ} \mathrm{C}$, respectively, and an average relative air humidity of $83 \%$ in the morning and $51 \%$ in the evening.

Once the dog owners agreed with the proposed procedures and signed the informed consent form, the ticks were removed from the dogs using hemostatic forceps with a vertical rotational movement, taking care to avoid separating the body from the mouthpiece. The greatest possible number of ticks was collected within a period of physical containment that prevented excessive stress to the animal. Following collection, the ticks were stored and transported in flasks containing absolute isopropanol. 
The species were identified morphologically using a binocular stereoscope. The ticks were separated into groups according to species, sex, and host. Females were stored individually, males in pools of up to seven individuals, and nymphs in pools of up to ten specimens; each species pool from the same animal was placed in a 1.5 $\mathrm{mL}$ microtube containing absolute isopropanol. Females, especially engorged ones, were processed individually because they exceeded the ideal weight for DNA extraction.

Figure 1. (A) Geographical location of the Department of Piura, Peru, South America. (B) Geographical location of the districts (names in green, inside of red circle) within the eight provinces (names in red) of the Department of Piura.

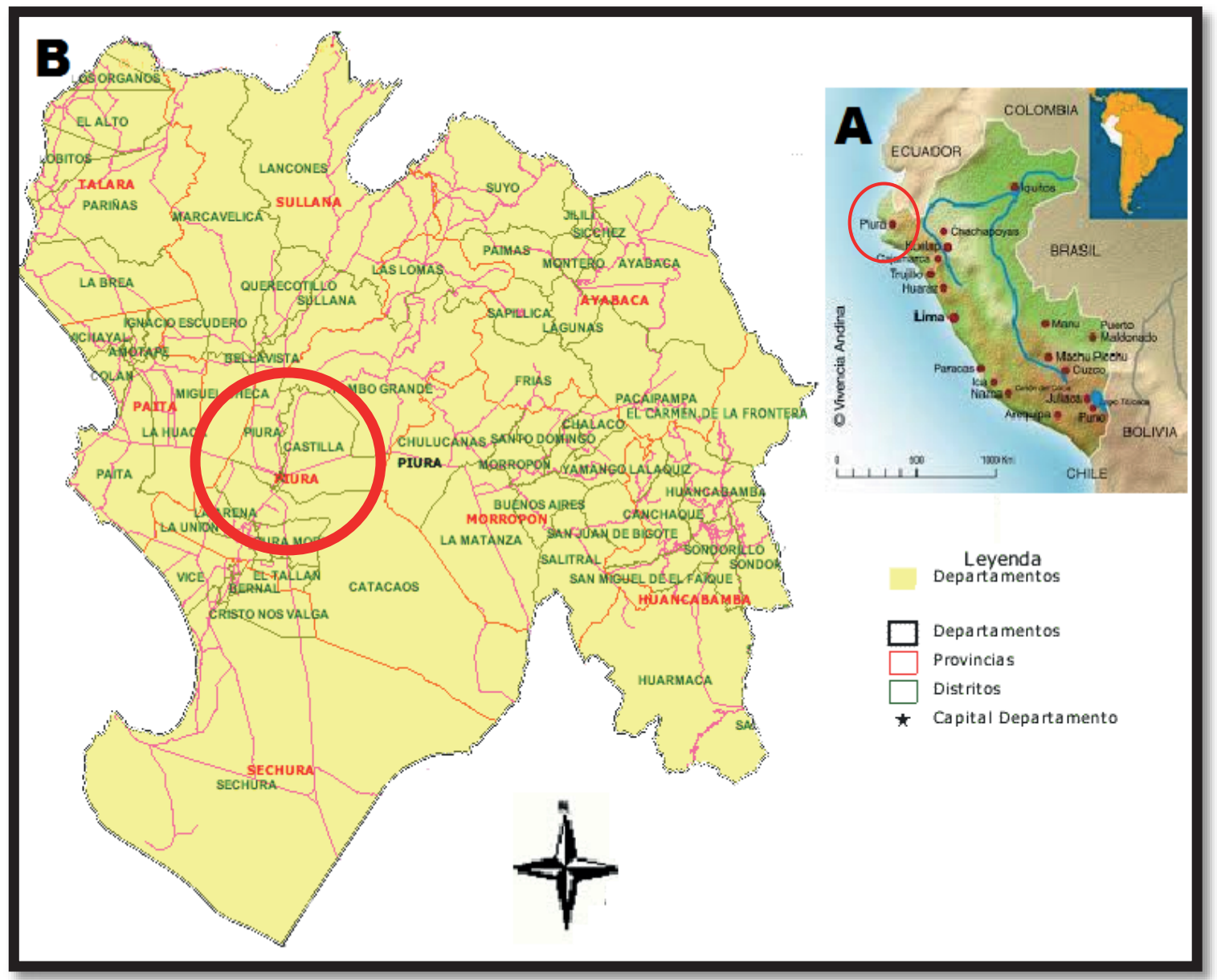

DNA was extracted from each tick sample using the tick DNA extraction method with phenol/ phenol-chloroform (SANTOLIN et al., 2013).

PCR amplification was conducted with primers Rr19O.70p/Rr19O.602n (EREMEEVA et al., 1994), BG1-21/BG2-20 (REGNERY et al., 1991), 17k-5/17k-3 (LABRUNA et al., 2004), and RpCS.877p/RpCS.1258n (REGNERY et al., 1991), which amplify fragments of approximately $532 \mathrm{bp}$,
$650 \mathrm{bp}, 549 \mathrm{bp}$, and $381 \mathrm{bp}$ of the ompA (membrane protein) ompB (membrane protein), htrA (a 17 $\mathrm{kDa}$ protein), and gltA (citrate synthase) genes, respectively.

The final concentrations of the reagents used were: $0.2 \mathrm{mM}$ of each $\mathrm{dNTP}, 10 \mu \mathrm{M}$ of each primer, $3.0 \mathrm{mM} \mathrm{MgCl} 2,1.25 \mathrm{U}$ GoTaq Flexi DNA Polymerase (Promega, Madison, WI, USA), 1× Green GoTaq Reaction Buffer, and $5 \mu \mathrm{L}$ of the DNA 
sample in a total reaction volume of $25 \mu \mathrm{L}$. The PCR reaction conditions included an initial DNA denaturation step at $95{ }^{\circ} \mathrm{C}$ for 5 minutes; followed by 40 consecutive cycles of $95^{\circ} \mathrm{C}$ for 40 seconds (denaturation), $55{ }^{\circ} \mathrm{C}$ for 60 seconds (annealing), and $72{ }^{\circ} \mathrm{C}$ for 70 seconds (extension); and a final extension at $72{ }^{\circ} \mathrm{C}$ for 7 minutes (REGNERY et al., 1991; EREMEEVA et al., 1994). For each reaction, a positive sample of $R$. parkeri strain At24 and a negative control (Ultra Pure TMD DNase/RNaseFree Distilled Water) were included.

The resulting products were visualized by electrophoresis on a $1.5 \%$ agarose gel stained with GelRed that was exposed to ultraviolet light to reveal the bands. A 100 base pair molecular weight marker (100 bp DNA Ladder, Invitrogen, Carlsbad, CA, USA) was used to determine the size of the amplified products.

The amplified PCR products from the positive samples were purified using the Illustra GFX PCR DNA and Gel Band Purification Kit commercial kit (GE Healthcare Life Sciences) and sequenced with a capillary-type Sanger platform on an ABI 3730 DNA Analyzer (Applied Biosystems, Life Technologies). The nucleotide sequences were compared to the corresponding homologs available in the National Center for Biotechnology Information (www.ncbi. nlm.nih.gov) GenBank database using the Basic Local Alignment Search Tool (BLAST; www.ncbi. nlm.nih.gov/blast.cgi).

The sequences were aligned using the Clustal W program version 2.1 and the alignment gaps were removed. Next, phylogenetic analysis was carried out using PHYLIP (Phylogeny Inference Package) with maximum stringency analysis and a bootstrap value of 1000 and a consensus tree was generated (using Seqboot, Dnapars, and Consense software). Graphical processing of the tree was performed with Mega version 6.06 software. The sequences used in the comparison were chosen because they cluster with $R$. felis according to the phylogeny proposed by Tsui et al. (2007); additional sequences of other
Rickettsia species were also used for comparison.

A total of 984 dog ticks were collected from 216 dogs. Only three species of ticks were identified: $977 R$. sanguineus (180 nymphs, 410 females, and 380 males), six Amblyomma triste females, and one Amblyomma tigrinum male. It is important to mention that ticks were grouped into 484 pools.

In a total of 484 tick pools, an infection rate of $0.2 \%(1 / 484)$ was determined by PCR. The positive tick was morphologically identified as $R$. sanguineus (adult female); analysis of the glt $A$ gene sequence obtained demonstrated 100\% (387 bp) identity with R. felis (KY887024). Although positive results were obtained for the gltA gene, no PCR product amplification was achieved for the $h \operatorname{tr} A, o m p A$, and ompB genes.

The vertebrate host of the tick was a 2-year-old dog from the Tacalá neighborhood in the Castilla district; the dog did not exhibit any clinical signs of disease.

The positive sample sequence (KY887024) was $97 \%$ and $98 \%$ identical to $R$. felis sequences isolated in Taiwan (AF210692) and Spain (AF540555), respectively. Phylogenetic analysis showed that the sequence grouped in the $R$. felis clade, as shown in Figure 2. Moreover, the isolate identified in this study (KY887024) demonstrated 92\% and 94\% identify with isolates obtained in Panama (HM582437) and Peru (GU117906), respectively. In addition, compared to other Rickettsia species, the sequence isolated in this study exhibited $93 \%$, 94\%, and 91\% identity with $R$. rickettsii (U59729), $R$. akari (U59717), and R. typhi (U59714) isolated in the USA, respectively.

Several surveys of $R$. felis in different countries have demonstrated that this agent has a worldwide distribution. $R$. felis has been identified in Ctenocephalides spp. fleas in Mexico, USA, Brazil, Peru, Ethiopia, Spain, and Germany (LABRUNA et al., 2011). However, it has also been reported in other species of fleas, mosquitoes, and ticks (CARDOSO et al., 2006, REIF; MACALUSO, 2009). 
This study is the first to confirm the presence of $R$. felis in $R$. sanguineus in Peru. Previous studies in Brazil have detected $R$. felis in Amblyomma sculptum (A. cajennense sensu lato) and in $R$. sanguineus using nested PCR and conventional PCR directed at the rickettsial $h$ tr $A$ gene. In addition, Tanikawa et al. (2013), were able to detect $R$. felis in $R$. sanguineus by conventional PCR and realtime PCR using the rickettsial gltA gene. Similar to the results of Cardoso et al. (2006), Oliveira et al. (2008), and Tanikawa et al. (2013), who failed to amplify other $R$. felis gene fragments from their tick specimens, no other rickettsial genes (ompA and $h \operatorname{tr} A$ ) could be amplified by standard PCR in this study. These negative PCR results could be due to the low rickettsial load in $R$. felis-infected $R$. sanguineus when using PCR protocols that amplify larger fragments, which are therefore less sensitive.

Figure 2. Phylogenetic tree based on the partial gltA gene sequence of the R. felis-positive sample from the metropolitan region of the province of Piura, Peru and similar sequences obtained from the GenBank database. Bootstrap values obtained after 1000 re-samplings are shown. The scale bar represents the difference (number of nucleotides) of each Rickettsia species within each branch. The sequence marked with $\left(^{*}\right)$ is the sample determined as Rickettsia spp.positive by PCR and confirmed by sequencing as $R$. felis.

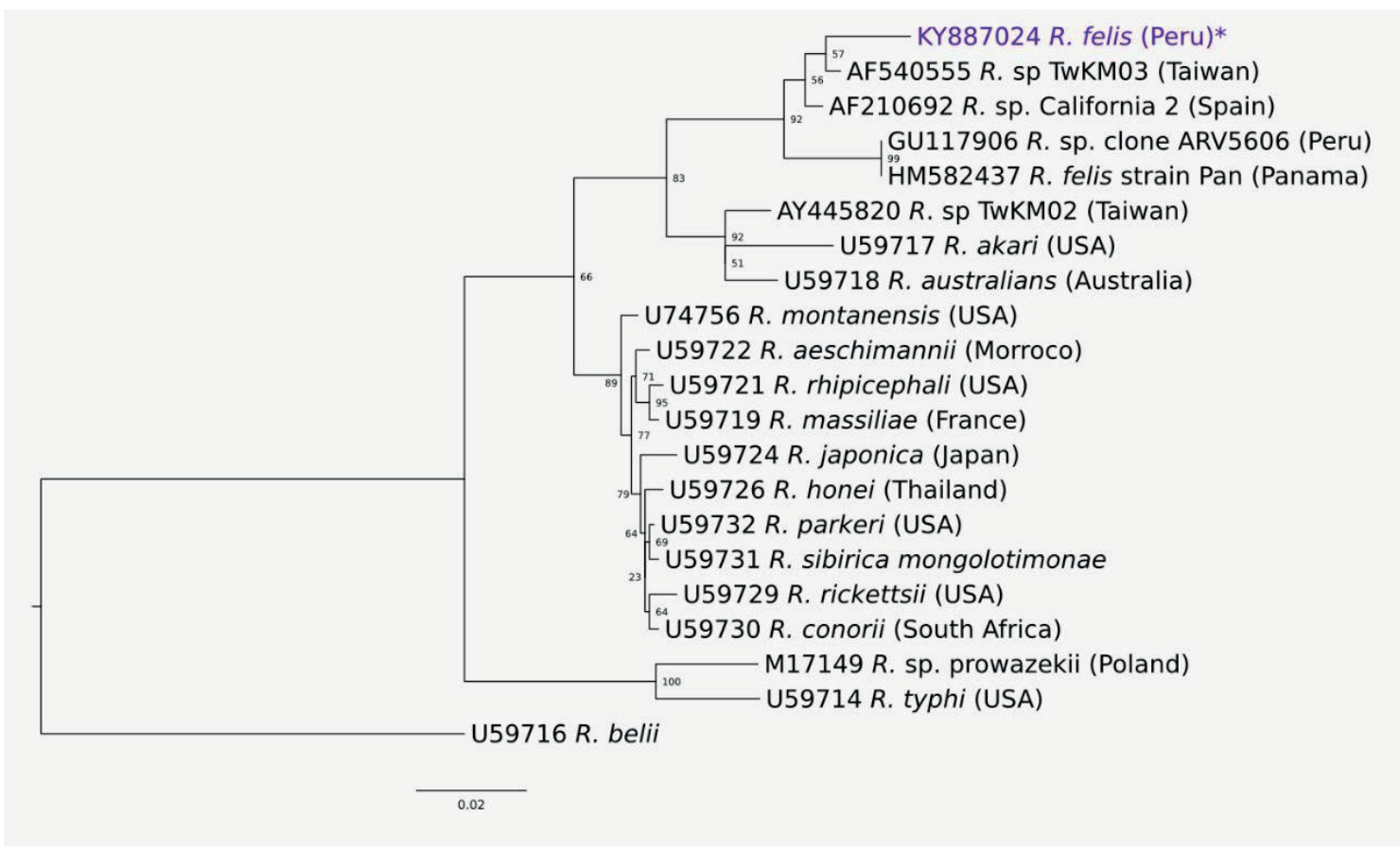

The role of this tick in the ecology and horizontal transmission of $R$. felis remains unclear (REIF; MACALUSO, 2009). It is likely that the source of $R$. sanguineus infection by $R$. felis is blood feeding from a host parasitized by $R$. felis-infected fleas. However, many rickettsial species exhibit robust growth in cell lines derived from ticks and other arthropods. Recently, the ISE6 tick cell line was used to isolate previously uncultured $R$. felis from cat fleas (PORNWIROON et al., 2006). If future studies confirm the ability of $R$. sanguineus to transmit $R$. felis, the results of the current study would support the need for tick and flea control in the prevention of spotted fever. 
Using molecular detection, Blair et al. (2004) identified the presence of SFG agents in three locations in rural areas of northwestern Peru (department of Piura); SFG was found in four of 16 ticks of the species Amblyommma maculatum, Dermacentor (Anocentor) nitens, and Ixodes boliviensis. In this study, the rate of infection by genus Rickettsia agents in dog ticks from the metropolitan region of Piura Province in the Department of Piura, Peru was $0.2 \%(1 / 484)$.

The low prevalence $(<2 \%)$ of rickettsia in epidemiological studies, even in regions considered endemic (SANGIONI et al., 2005), can be explained by the high pathogenicity of some species of Rickettsia in the vector, resulting in a low survival rate. In addition, the presence of vertebrate hosts with a degree of bacteremia sufficient to infect new susceptible ticks must be considered (SOARES et al., 2012).

Previous studies have demonstrated the efficacy of both dogs and other species as indicators of spotted fever agents (SANGIONI et al., 2005). Based on the results observed in the metropolitan region of Piura, it can be concluded that dogs may constitute an important indicator of the spotted fever agent; thus, future research should screen dogs for ticks.

\section{Acknowledgements}

We wish to especially acknowledge the Coordenação de Aperfeiçoamento de Pessoal de Nível Superior (Capes) and the Fundação de Amparo à Pesquisa do Estado do Rio de Janeiro (FAPERJ).

\section{References}

BLAIR, P. J.; JIANG, J.; SCHOELER, G. B.; MORON, C.; ANAYA, E.; CESPEDES, M.; CRUZ, C.; FELICES, V.; GUEVARA, C.; MENDOZA, L.; VILLASECA, P.; SUMNER, J. W.; RICHARDS, A. L.; OLSEN, J. G. Characterization of spotted fever group rickettsiae in flea and tick specimens from northern Peru. Journal of Clinical Microbiology, Washington, v. 42, n. 11, p. 49614967, 2004.

CARDOSO, L. D.; FREITAS, R. N.; MAFRA, C. L.; NEVES, C. V.; FIGUEIRA, F. C.; LABRUNA, M. B.; GENNARI, S. M.; WALKER, D. H.; GALVÃO, M. A. Characterization of Rickettsia spp. circulating in a silent peri urban focus for Brazilian spotted fever in Caratinga, Minas Gerais, Brazil. Cadernos de Saúde Pública, Rio de Janeiro, v. 22, n. 3, p. 495-501, 2006.

EREMEEVA, M. E.; ZAMBRANO, M. L.; ANAYA, L.; BEATI, L.; KARPATHY, S. E.; SANTOS-SILVA, M. M.; SALCEDA, B.; MACBETH, D.; OLGUIN, H.; DASCH, G. A.; ARANDA, C. A. Rickettsia rickettsii in Rhipicephalusticks, Mexicali, Mexico. Journal of Medical Entomology, Oxford, v. 48, n. 2, p. 418-421, 2011.

EREMEEVA, M.E.;YU, X.; RAOULT, D. Differentiation among spotted fever group Rickettsiae species by analisis of restriction fragment length polymorphism of PCR-amplified DNA. Journal of Clinical Microbiology, Washington, v. 32, n. 3, p. 803-810, 1994.

FORSHEY, B. M.; STEWART, A.; MORRISON, A. C.; GÁlVEZ, H.; ROCHA, C.; ASTETE, H.; EZA, D.; CHEN, H. W.; CHAO, C. C.; MONTGOMERY, J. M.; BENTZEL, D. E.; CHING, W. M.; KOCHEL, T. J. Epidemiology of spotted fever group and typhus group rickettsial infection in the Amazon Basin of Peru. The American Journal of Tropical Medicine and Hygiene, Baltimore, v. 82, n. 4, p. 683-690, 2010.

LABRUNA, M. B.; MATTER, S.; NAVA, S.; BERMUDEZ, S.; VENZAL, J. M.; DOLZ, G.; ABARCA, K.; ROMERO, L.; SOUSA, R. de; OTEO, J.; ZAVALA-CASTRO, J. Rickettsioses in Latin America, Caribbean, Spain and Portugal. Revista MVZ Córdoba, Córdoba, v. 16, n. 2, p. 2435-2457, 2011.

LABRUNA, M. B.; WHITWORTH, T.; HORTA, M. C.; BOUYER, D. H.; MCBRIDE, J. W.; PINTER, A.; POPOV, V.; GENNARI, S. M.; WALKER, D. H. Rickettsia species infecting Amblyomma cooperi ticks from an area in the state of Sao Paulo, Brazil, where Brazilian spotted fever is endemic. Journal of Clinical Microbiology, v. 42, n. 1, p. 90-98, 2004. 
OLIVEIRA, K. A.; OLIVEIRA, L. S.; DIAS, C. C.; SILVA JÚNIOR, A.; ALMEIDA, M. R.; ALMADA, G.; BOUYER, D. H.; GALVAO, M. A.; MAFRA, C. Molecular identification of Rickettsia felis in ticks and fleas from an endemic area for Brazilian spotted fever. Memórias do Instituto Oswaldo Cruz, Rio de Janeiro, v. 103, n. 2, p. 191-194, 2008.

PORNWIROON, W.; POURCIAU, S. S.; FOIL, L. D.; MACALUSO, K. R. Rickettsia felis from cat fleas: isolation and culture in a tick-derived cell line. Applied and Environmental Microbiology, Washington, v. 72, n. 8, p. 5589-5595, 2006.

REGNERY, R. L.; SPRUILL, C. L.; PLIKAYTIS, B. D. Genotypic identification of Rickettsiae and estimation of intraspecies sequence divergence for portions of two Rickettsial genes. Journal of Bacteriology, Washington, v. 173, n. 5, p. 1576-1589, 1991.

REIF, K. E.; MACALUSO, K. R. Ecology of Rickettsiafelis: a review. Journal of Medical Entomology, Oxford, v. 46, n. 4, p. 723-736, 2009.

SANGIONI, L. A.; HORTA, M. C.; VIANNA, M. C.; GENNARI, S. M.; SOARES, R. M.; GALVAO, M. A.; SCHUMAKER, T. T.; FERREIRA, F.; VIDOTTO, O.; LABRUNA, M. B. Rickettsia infection in animals and Brazilian spotted fever endemicity. Emerging Infectious Diseases, Atlanta, v. 11, n. 2, p. 265-270, feb. 2005.
SANTOLIN,Í.D.A.C.; FAMADAS, K. M.; MCINTOSH, D. Detection and identification of Rickettsia agents in ticks collected from wild birds in Brazil by polymerase chain reaction-restriction fragment length polymorphism (PCR-RFLP) analysis. Revista Brasileira de Medicina Veterinária, Rio de Janeiro, v. 35, n. 2, p. 68-73, 2013.

SOARES, J. F.; SOARES, H. S.; BARBIERI, A. M.; LABRUNA, M. B. Experimental infection of the tick Amblyomma cajennense, Cayenne tick, with Rickettsia rickettsii, the agent of Rocky Mountain spottedfever. Medical and Veterinary Entomology, Oxford, v. 26, n. 2, p. 139-151, 2012.

TANIKAWA, A.; COSTA, F. B.; LABRUNA, M. B.; AZEVEDO, S. S. de. A survey for rickettsial agents on Rhipicephalus sanguineus (Ixodida, Ixodidae) ticks in Northeastern Brazil. Brazilian Journal of Veterinary Research and Animal Science, São Paulo, v. 50, n. 5, p. 414-417, 2013.

TSUI, P. Y.; TSAI, K. H.; WENG, M. H.; HUNG, Y. W.; IU, Y. T.; HU, K. Y.; LIEN, J. C.; LIN, P. R.; SHAIO, M. F.; WANG, H. C.; JI, D. D. Molecular detection and characterization of spotted fever group rickettsiae in Taiwan. The American Journal of Tropical Medicine and Hygiene, Baltimore, v. 77, n. 5. p. 883-890, 2007. 
